\title{
Limnological variability and pelagic fish abundance (Stolothrissa tanganicae and Lates stappersii) in Lake Tanganyika
}

\author{
P.-D. Plisnier $\cdot$ H. Mgana $\cdot$ I. Kimirei $\cdot$ A. Chande $\cdot$ L. Makasa $\cdot$ \\ J. Chimanga $\cdot$ F. Zulu $\cdot$ C. Cocquyt $\cdot$ S. Horion $\cdot$ N. Bergamino $\cdot$ \\ J. Naithani $\cdot$ E. Deleersnijder $\cdot$ L. André $\cdot$ J.-P. Descy $\cdot$ Y. Cornet
}

Received: 24 June 2008/Revised: 12 December 2008/ Accepted: 2 January 2009

(C) Springer Science+Business Media B.V. 2009

\begin{abstract}
The abundance of two main pelagic fish species in Lake Tanganyika (Stolothrissa tanganicae and Lates stappersii) has always been observed to fluctuate considerably at different time scales. The inverse correlation between the abundance of these species has often been interpreted as the consequence of predator-prey relations (avoidance behaviour by the prey). However, currently the two species often appear spatially segregated in the lake, S. tanganicae dominating in the north while $L$. stappersii is generally abundant in the south where it feeds mostly on shrimps. A fluctuating abundance of the species is
\end{abstract}

Handling editor: M. Power

P.-D. Plisnier $(\bowtie) \cdot$ L. André

Royal Museum for Central Africa, Tervuren, Belgium

e-mail: pierre-denis.plisnier@africamuseum.be

H. Mgana $\cdot$ I. Kimirei · A. Chande

Tanzania Fisheries Research Institute, Kigoma, Tanzania

L. Makasa $\cdot$ J. Chimanga $\cdot$ F. Zulu

Department of Fisheries, Mpulungu, Zambia

C. Cocquyt

National Botanic Garden of Belgium, Meise, Belgium

S. Horion - Y. Cornet

Unit of Geomatics, Department of Geography, University of Liège, Liège, Belgium

N. Bergamino

Dip. di Scienze e Tecnologie Chimiche e dei Biosistemi, Università degli Studi di Siena, Siena, Italy nevertheless observed. As these fish species have a major importance for the fisheries, we investigated the limnological variability in relation to the shortterm variability of fish catches. The abundance of $S$. tanganicae was positively correlated to plankton biomass $(r=0.65)$, while water transparency $(r=0.56)$, depth of mixed layer $(r=-0.70)$ and oxygenated water appeared important drivers for the abundance of L. stappersii. Alternating "mixing" and "stable" states of the epilimnion related to seasonal and internal waves variability are probably determinant for the short-term variability in abundance of 
S. tanganicae and L. stappersii. In the framework of this study, remote sensing has shown a potentially interesting application for fisheries research at Lake Tanganyika. We observed a close correspondence between phytoplankton blooms at the time of trade winds changes and increased catches of $S$. tanganicae in the south. The anti-correlated abundance of $S$. tanganicae and L. stappersii probably mainly reflects the underlying fluctuating limnological environment. Fisheries studies need to integrate limnological and planktonic monitoring to better understand large and complex ecosystems such as Lake Tanganyika.

Keywords Stolothrissa tanganicae .

Lates stappersii · Tanganyika · Fisheries ·

Visual predation $\cdot$ Predator-prey

\section{Introduction}

The accelerated loss in biodiversity in the world fish population points towards the urgent need for increased understanding of parameters controlling this resource (Jackson et al., 2001; Worm et al., 2006). A preliminary step is to better understand short-term variability of fishes in relation with their environment. This is particularly needed from areas of the world of great biodiversity importance such as the African Rift (Plumptre et al., 2007) where signs of climate change are observed (O'Reilly et al., 2003; Verburg et al., 2003).

Lake Tanganyika is a major lake $\left(32,000 \mathrm{~km}^{2}\right)$ of the Albertine Rift Valley in East Africa. The main species exploited are currently two endemic clupeid species, Stolothrissa tanganicae Regan 1917 and Limnothrissa miodon (Boulenger, 1906), and an endemic perciform of the Latidae family, Lates stappersii (Boulenger, 1914). Annual fishing production at Lake Tanganyika has been estimated to vary in the range from 165,000 to 200,000 tons (Mölsä et al., 1999). A potential yield of $100 \mathrm{~kg} \mathrm{ha}^{-1} \mathrm{yr}^{-1}$ has been estimated (Coulter, 1977).

A high temporal and spatial variability of pelagic fish catches has always been observed in this lake (Mann, 1973; Coulter, 1991; Phiri \& Shirakihara, 1999). Interannual changes (3-7 years) in species dominance in the catches of Lates stappersii and clupeids have been attributed to predator-prey relationship (Herman, 1978; Pearce, 1988) and variable recruitment in relation to environmental conditions (Coulter, 1991), while short term fluctuations (daily, weekly...) were related to avoidance of their predator L. stappersii by the clupeid prey (Pearce, 1988; Roest, 1988).

Some main biological characteristics of Lake Tanganyika pelagic fishes were summarised by Coulter (1991). Stolothrissa tanganicae reaches a maximum size of $100 \mathrm{~mm}$ (standard length, SL), while longevity was estimated at 1.5 years. It lives in the depth range of 8-60 $\mathrm{m}$ and forms very large schools. S. tanganicae seems to stay below about $60 \mathrm{~m}$ during the day, rising up to $8-15 \mathrm{~m}$ at night. Juvenile Stolothrissa feed mainly on phytoplankton while the adults feed mainly on copepods, particularly the calanoid Tropodiaptomus simplex, and shrimps. Lates stappersii reaches a maximum size of $450 \mathrm{~mm}$ (SL) and has a life span of about six years. Young L. stappersii feed mainly on the pelagic zooplankton Mesocyclops or Tropodiaptomus and shrimps of the genus Limnocaridina until they reach about $130 \mathrm{~mm}$ in length when they switch from a diet of zooplankton and become piscivorous (Chèné, 1975; Ellis, 1978). Clupeids and shrimps alternate in their diet depending on the time of the year, area of the lake and their abundance in the environment (Mannini et al., 1999).

Recent results have shown that limnological conditions and planktonic resources exhibit also a high spatial and temporal variability at various time scales (Descy et al., 2005; De Wever et al., 2007; Bergamino et al., 2007). To investigate possible links between short term fluctuations of environment and abundance of the main pelagic fish (Stolothrissa tanganicae and Lates stappersii), thus, limnological, fishery and remote sensing survey were carried out at two sites of Lake Tanganyika, in the period 20042006.

\section{Material and methods}

Environmental parameters

We implemented a limnological monitoring at Kigoma in the north of the lake and Mpulungu in the south (Descy et al., 2005; Plisnier \& Descy, 2005; 


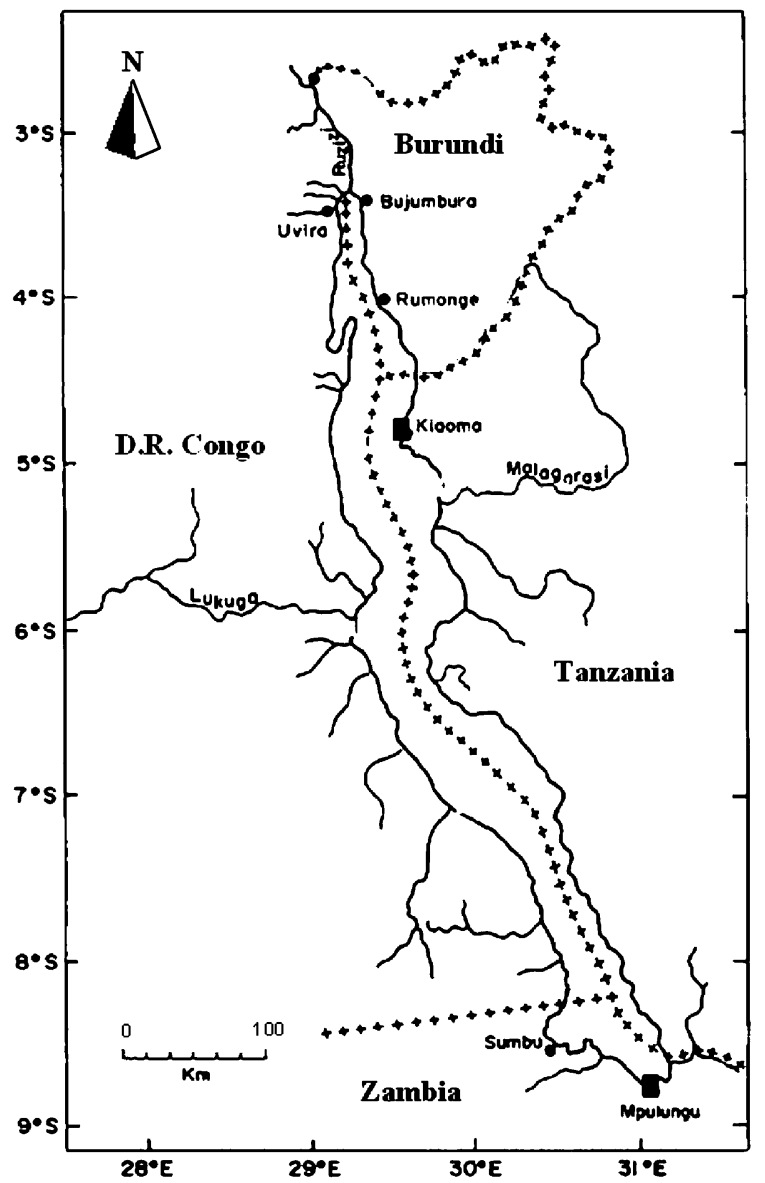

Fig. 1 Map of Lake Tanganyika

De Wever et al., 2007; Kimirei \& Mgaya, 2007). The sampling took place every two weeks at sites located $4^{\circ} 51^{\prime} 57^{\prime \prime}$ S, $29^{\circ} 35^{\prime} 31.2^{\prime \prime}$ E (CLIMP-K) near Kigoma in Tanzania and $8^{\circ} 43^{\prime} 57^{\prime \prime} \mathrm{S}, 31^{\circ} 02^{\prime} 24^{\prime \prime} \mathrm{E}$ (CLIMP-M) near Mpulungu in Zambia (Fig. 1).

Temperature profiles were measured using a CTD probe (Seabird 19 in Kigoma, Hydrolab DS4 in Mpulungu). Dissolved oxygen (DO), $\mathrm{pH}$ and turbidity were occasionally measured with the CTD probes or with a Yellow Spring Instrument, a Hanna $\mathrm{pH}$-meter and a Hach turbidimeter, respectively. The water transparency was measured with a standard white Secchi disc (SD) of $30 \mathrm{~cm}$ diameter. Euphotic depth (depth at which light is $1 \%$ of subsurface light, $Z_{\mathrm{eu}}$ ) was derived from Secchi depth by calculating the vertical light attenuation coefficient $\left(k=1.57 / \mathrm{SD}, \quad Z_{\mathrm{eu}}=\right.$ $4.6 / \mathrm{k})$. The conversion coefficient was obtained by calibration with measurement of photosynthetically active radiation (PAR) downward attenuation with LICOR quantum sensors. The depth of mixing $\left(Z_{\mathrm{m}}\right)$ was estimated from the inflexion point of the vertical profiles of water temperature, $\mathrm{pH}$ and conductivity (and DO when available), in the upper layer of the lake $(0-100 \mathrm{~m})$. In the mixolimnion, the values of these parameters display little variability such as quasihomothermal conditions while a regular decrease of temperature, $\mathrm{pH}$ and DO matching with an increased conductivity indicated the most likely depth for $Z_{\mathrm{m}}$.

The water column stability is the work necessary to reach homothermal conditions allowing the lake water to mix. For Lake Tanganyika, it is mainly dependent on density differences driven by water temperature differences. The probability of nutrientrich deep waters accessing the surface water is increased when the stability is low. We have calculated the stability for the upper $100 \mathrm{~m}$ of the water column using the potential energy anomaly (PEA) according to Simpson et al. (1982). The PEA (in $\mathrm{J} \mathrm{m}^{-3}$ ) is correlated with several limnological variables (De Wever et al., 2007).

Chlorophyll $a(\mathrm{Chl} a)$ concentrations were measured every $20 \mathrm{~m}$ from the surface down to $100 \mathrm{~m}$ by high performance liquid chromatography (HPLC) on preserved samples at Kigoma as described in Descy et al. (2005) and by fluorometric measurement using a Turner Designs T7-1A fluorometer in Mpulungu (Plisnier \& Descy, 2005). Chlorophyll pigment concentration and phytoplankton carbon content can be variable but are commonly used as surrogates of productivity often used in primary productivity models (Fennel \& Boss, 2003). We have confirmed that Chl $a$ is a good planktonic indicator at Lake Tanganyika by using phytoplanktonic biovolumes from algae following the Uthermöhl method (Cocquyt \& Vyverman, 2005; Uthermöhl, 1931).

Chlorophyll $a$ concentration and K490, the light attenuation coefficient, were also measured for the surface water of the whole lake by remote sensing from satellite images for the period from 07/2002 to 12/2006. During this period, respectively, 662 and 652 daily images of Chl $a$ and K490 were produced assuming the Case Water 1 hypothesis. Indeed the light attenuation coefficient at $490 \mathrm{~nm}$ is related to water column turbidity (light scattering) and absorption (attenuation), both dominated by phytoplankton growth in the pelagic area of the Lake. Both time series were extracted from Level 1B MODIS images 
containing calibrated and geolocated radiances at-aperture for all 36 MODIS Aqua spectral bands at $1 \mathrm{~km}$ resolution. The msl12 module of SeaDAS 4.6 software was used for the atmospheric correction and the selection of the best bio-optical algorithms for Chl $a$ and K490 extraction. The "calibration" of this extraction process was achieved with in situ data collected during three lake wide cruises and the time series validation was performed using in situ data collected at the permanent stations. The most accurate results were obtained using an atmospheric correction estimating Rayleigh diffusion from the lake height, using a constant relative humidity of $90 \%$ and a coastal aerosol multi-scattering model. The OC3 bio-optical algorithm concentration was the most efficient for the estimation of $\mathrm{Chl} a\left(r^{2}\right.$ for validation $=0.88$ ). It is specifically designed for the MODIS imagery. The remotely sensed attenuation coefficient at $490 \mathrm{~nm}$ was also calculated with a good level of accuracy using the default algorithm of the msl12 module $\left(r^{2}\right.$ for validation $\left.=0.96\right)$. All daily images could not be used because of cloudiness, the percentage of exploitable images being $18.5 \%$ at Kigoma and $37.2 \%$ at Mpulungu.

\section{Fisheries data}

Fish statistics were collected in the north (Kigoma) at three beaches (Katonga, Kibirizi and Kigodeco) from the lift net artisanal fishery. This technique of fishing is used in most of the lake except in the south. A typical catamaran fishing unit consists of two 6-7 m long mainly wooden plank hulls, a lift net (55-65 $\mathrm{m}$ circumference), 6-7 lamps and an average of 6 fishermen. Lamps are used to attract the fishes during the night and nets are cast several times each night.

Each beach was visited twice per month and a total of 213 visits to these landing beaches was carried out from 01/2003 to 04/2006. The catches from nine lift net units at each of the three beaches were sampled. A subsample of small fishes was sorted in the laboratory to deduce the proportions of the fish species. The data from the three beaches were compared and no significant difference was found; thus, the data from those sites were processed as one set ordered chronologically.

In the south of the lake, "ring nets" were sampled at Mpulungu on Ngwenya beach from 07/2004 to
08/2006 during a total of 158 visits. The ring net fishing is an artisanal fishing method developing there since several years. It is relatively similar to purseseining: a net is actively encircling fishes that are attracted by lights during the night. However, the wooden boat and the net used by ring net units are much smaller than purse seines, which allow faster manoeuvring. The number of ring net units of fishing operating in the south was estimated to be 156 in 2006. In addition, fisheries statistics from the industrial fisheries (purse seine) in the south were compiled in Mpulungu for the period from 01/2002 to 05/2006. About 20 units of industrial purse seine fishing are operating there. This fishing is generally not operating during the main annual southern upwelling season (July and August).

Two indicators have been used for estimating fish abundance: the catch per unit of effort (CPUE) and the occurrence index (OI) (Bannerot \& Austin, 1983). The CPUE may be used as an indicator of local fish abundance and is the most commonly used index of fish density (Gulland, 1983; Plisnier et al., 1988; Roest, 1993; Sanyanga et al., 1995; Mannini, 1998), although the use of CPUE has known limitations to take into consideration when interpreting results (Mangel \& Smith, 1990; Barnes et al. 1992) such as changes in efficiency of the effort over time. However, during the present study, it is considered that there were no significant changes in efficiency. For artisanal fishing, the unit of effort considered here was the fishing during one night per lift net unit at Kigoma and per ring net unit at Mpulungu. For industrial fishing in Mpulungu, the unit was the fishing during one night by a purse seiner. The OI of one species was calculated as the frequency of non-zero catches during the fishing period.

Every month, the fishing ceases during the full moon period (about 7 days per month) as the attraction of the fishermen's lights is too low compared to moonlight. Fish statistics were thus collected over a period of about 23 days each month.

The analyses were done separately for Kigoma and Mpulungu as the fishing methods were different. These fishing methods are not very selective compared to other methods (FAO, 1984). The proportions of fishes of different species caught were compared between Kigoma and Mpulungu. The difference in relative abundance between fish 
species in those two areas was in agreement with previous observations using trawling experiments in both areas in 1995-1998 (Mannini, 1998). The autocorrelation function (ACF) of the CPUE times series was calculated for monthly lags up to 15 months. We calculated cross-correlation between CPUE of the target species and environmental variables at -15 to +15 months lag periods to estimate possible periodicity and compared with critical values for correlation coefficients (Rohlf \& Sokal, 1995).

The relationship between CPUE of Lates stappersii and Stolothrissa tanganicae and environmental variables for artisanal fishing in Kigoma and Mpulungu and in Mpulungu for industrial fishing was analysed. In order to address the high correlations between environmental variables, a multiple linear forward stepwise regression was used. As with other procedures to avoid the multi-co-linearity effects (Dagnelie, 1986), the stepwise procedure allows the analysis of redundancy between independent variables through the tolerance parameter (Patti et al., 2008). Furthermore, we also introduced in the set of independent variables the possible predator-prey interactions using CPUE of each species in the modelling. This regression analysis was applied to raw data because the short-time period of time series precluded the elimination of any trend or seasonality.

\section{Results}

The relative abundance of the target pelagic species was different between the northern and southern parts of the lake calculated over the same period (20042006) from the sampled units. It showed the predominance $(83.1 \%$ by weight) of Stolothrissa tanganicae, in the north compared to Lates stappersii (15.7\%), while inversely, in the south, L. stappersii dominated in the catches $(82.1 \%)$ compared to S. tanganicae (10.7\%) (Table 1). ${ }^{1}$

\footnotetext{
$\overline{1}$ A third species was also occasionally caught by pelagic fishermen: Limnothrissa miodon. This species is common in the south but represents a small percentage of the weight of catches (7\%) and is only partially pelagic (Poll, 1953; Mannini et al., 1996).
}

The occurrence index confirmed that Lates stappersii was less common in the catches in the north although not in the same proportion as for the weight proportion indicating that individuals of this species may be caught often but in reduced abundance compared to Stolothrissa tanganicae. In the south, the very low occurrence of $S$. tanganicae indicated that the relative abundance of this species is spatially very heterogenous.

\section{Catches of Stolothrissa tanganicae and limnological data}

The CPUE of Stolothrissa tanganicae in Kigoma increased significantly $(r=0.65, P<0.01)$ with Chl $a$ at Kigoma (Fig. 2). Surface Chl $a$ measured by remote sensing in 2004-2006 showed also a positive significant correlation $(r=0.54, P<0.01)$ with the catches of $S$. tanganicae in Kigoma. There was a negative correlation between the temperature in the upper water and the catches of S. tanganicae, which were also negatively correlated with PEA and with water transparency (Table 2). The well-known inverse correlation between CPUE of $S$. tanganicae and Lates stappersii (Roest, 1988; Pearce, 1988) was observed at Kigoma $(r=-0.45)$. However, the correlation was stronger between CPUE of S. tanganicae and several limnological variables, particularly the planktonic abundance (Table 2). It is also worth noting that, although $L$. stappersii catches decreased strongly after October 2004 at Kigoma, the CPUE of $S$. tanganicae remained well related with the variations of Chl $a$ concentration (Fig. 2). The correlograms of CPUE time series indicated a probable seasonal cyclicity of Stolothrissa tanganicae near Kigoma with significant inverse correlation at 6 months lag time. An increased correlation was also noted with a 1012 months lag time but it was not significant (Fig. 3A). Cross-correlation with environmental variables indicated a seasonal cyclicity with temperature, stability, mixing zone, transparency and Chl $a$ in the North (Fig. 4A).

For artisanal fishing in Kigoma, the stepwise regression model explaining the Stolothrissa tanganicae CPUE showed that the predation by Lates stappersii does not have any significant influence. 
Table 1 Percentages of fish species (Lates stappersii, Stolothrissa tanganicae and Limnothrissa miodon) caught in the pelagic area (weight and occurrence indice; sampled fishing units $N=867$ in Kigoma and 552 in Mpulungu)

\begin{tabular}{llllcrrr}
\hline & & & L. stappersii & S. tanganicae & L. miodon \\
\hline \multirow{2}{*}{ Kigoma } & Tot W (kg) & 265957 & W\% & 15.7 & 83.1 & 1.2 \\
& Occurrence(\%) & & OI\% & 69.2 & 95.8 & 22.6 \\
\multirow{3}{*}{ Mpulungu } & Tot W (kg) & 208067 & W\% & 82.1 & 10.7 & 7.2 & 75.2 \\
& Occurrence(\%) & & OI\% & 89.7 & 27.0 & \\
\hline
\end{tabular}

Fig. 2 Catches per unit of effort (lift nets) of Lates stappersii (A), Stolothrissa tanganicae (B), Chl a (0-20 m) from HPLC (C), surface Chl $a(\mathbf{D})$ and extinction coefficient $\mathrm{K}_{490}$ (E) from remote sensing (RS), transparency (F), potential energy anomaly (G) and average water $\mathrm{T}^{\circ}$ (0-20 m) (H) from January 2003 to April 2006 at Kigoma. Average monthly observations $=6(\mathbf{A}, \mathbf{B}), 2$ $(\mathbf{C}, \mathbf{G}, \mathbf{G}, \mathbf{H}) \& 2.7(\mathbf{C}, \mathbf{D})$
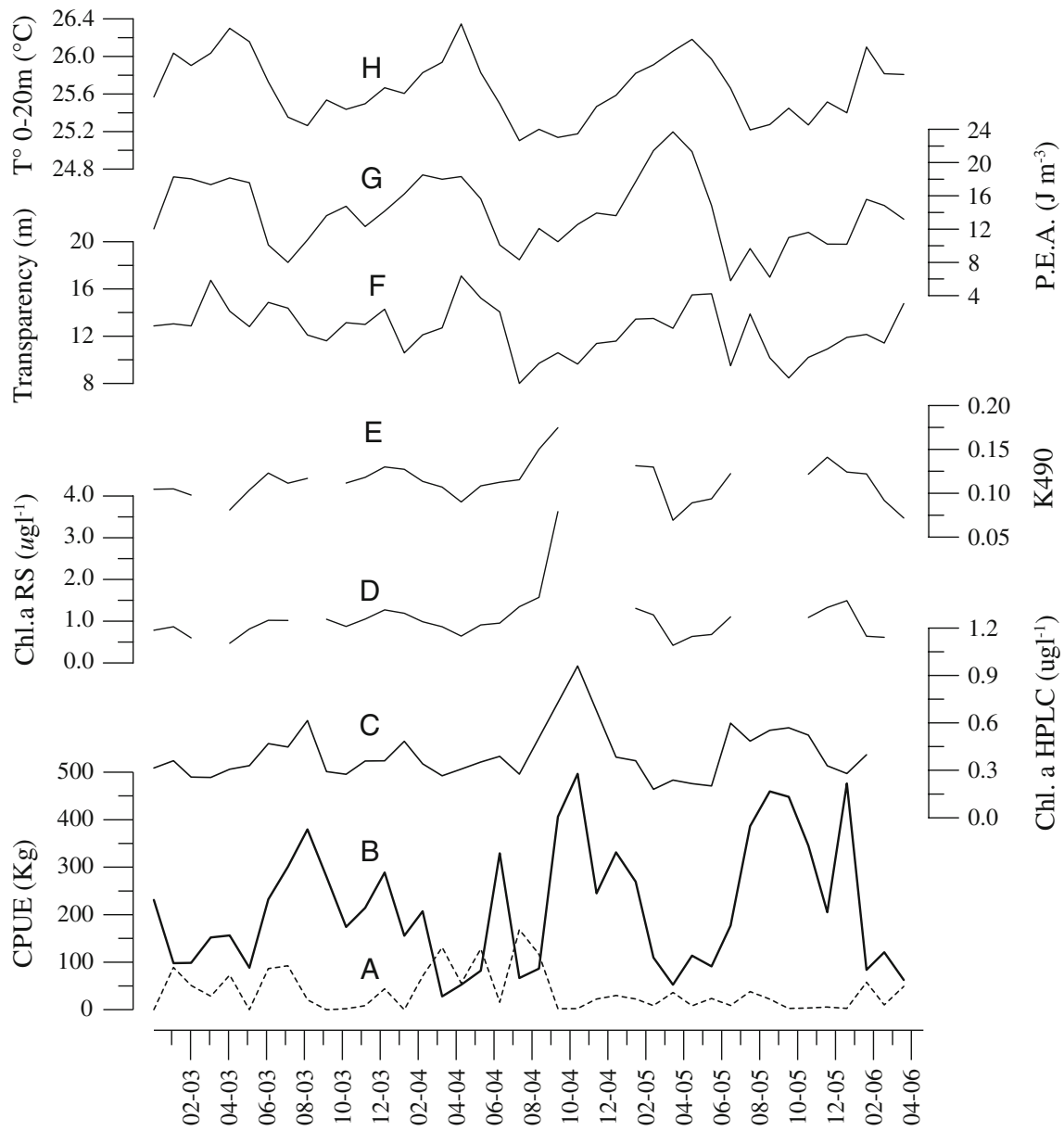

Indeed the variable L. stappersii CPUE was not selected in the forward stepwise procedure applying a minimum threshold of 1 for the $F$-statistics criterion used. The four environmental variables selected by the procedure were: water temperature $(0-20 \mathrm{~m})$, Chl $a, \mathrm{~K} 490$ and PEA (Table 3). The final model explained nearly $70 \%$ of the variance of $S$. tanganicae CPUE. Partial correlations between $S$. tanganicae CPUE and the four variables $(-0.38, \quad 0.51, \quad-0.41$ and -0.29 , respectively) showed the predominant positive effect of phytoplankton concentration on the CPUE of Stolothrissa 
Table 2 Pearson coefficients of correlation between monthly artisanal fisheries CPUE of Stolothrissa tanganicae and Lates stappersii and limnological variables at Kigoma from 01/2003 to 04/2006 (site CLIMP-K)

\begin{tabular}{|c|c|c|c|c|c|c|c|c|c|}
\hline & $\begin{array}{l}\text { CPUE } \\
\text { Stolo }\end{array}$ & $\begin{array}{l}\text { CPUE } \\
\text { Lstp }\end{array}$ & S.D. & $Z_{\mathrm{m}}$ & PEA & $\begin{array}{l}\text { Chla HPLC } \\
0-20 \mathrm{~m}\end{array}$ & $\begin{array}{l}\text { Chla } \\
\text { RS }\end{array}$ & $\begin{array}{l}\text { K490 } \\
\text { RS }\end{array}$ & $\begin{array}{l}\mathrm{T}^{\circ} \mathrm{Ki} \\
0-20 \mathrm{~m}\end{array}$ \\
\hline CPUE Stolo & 1.00 & & & & & & & & \\
\hline CPUE Lstp & -0.45 & 1.00 & & & & & & & \\
\hline S.D. & -0.45 & 0.31 & 1.00 & & & & & & \\
\hline$Z_{\mathrm{m}}$ & -0.30 & 0.14 & 0.11 & 1.00 & & & & & \\
\hline PEA & -0.58 & 0.03 & 0.41 & -0.11 & 1.00 & & & & \\
\hline Chla HPLC 0-20 m & 0.65 & -0.19 & -0.58 & -0.03 & $-\mathbf{0 . 5 3}$ & 1.00 & & & \\
\hline Chla RS & 0.54 & -0.10 & -0.41 & -0.24 & -0.43 & 0.29 & 1.00 & & \\
\hline K490 RS & 0.51 & -0.09 & -0.54 & -0.25 & -0.46 & 0.41 & 0.85 & 1.00 & \\
\hline $\mathrm{T}^{\circ} \mathrm{Ki} 0-20 \mathrm{~m}$ & -0.67 & 0.09 & 0.59 & 0.20 & 0.77 & -0.55 & -0.64 & -0.63 & 1.00 \\
\hline
\end{tabular}

CPUE: catch per night of fishing by a lift nets unit, S.D. = secchi disc transparency, $Z_{\mathrm{m}}=$ mixed layer depth, PEA $=$ potential energy anomaly from 0 to $100 \mathrm{~m}, \mathrm{Chl} a \mathrm{HPLC}=$ average Chl $a$ measured by HPLC at 0 and $20 \mathrm{~m}$ depth, Chl $a \mathrm{RS}=$ surface Chl $a$ measured by remote sensing, K490 RS = coefficient of extinction measured by remote sensing, $\mathrm{T}^{\circ} 0-20 \mathrm{~m}=$ average lake $\mathrm{T}^{\circ}$ at 0 and $20 \mathrm{~m}$; in bold: significant at $P<0.01$, in italic: significant at $P<0.05$

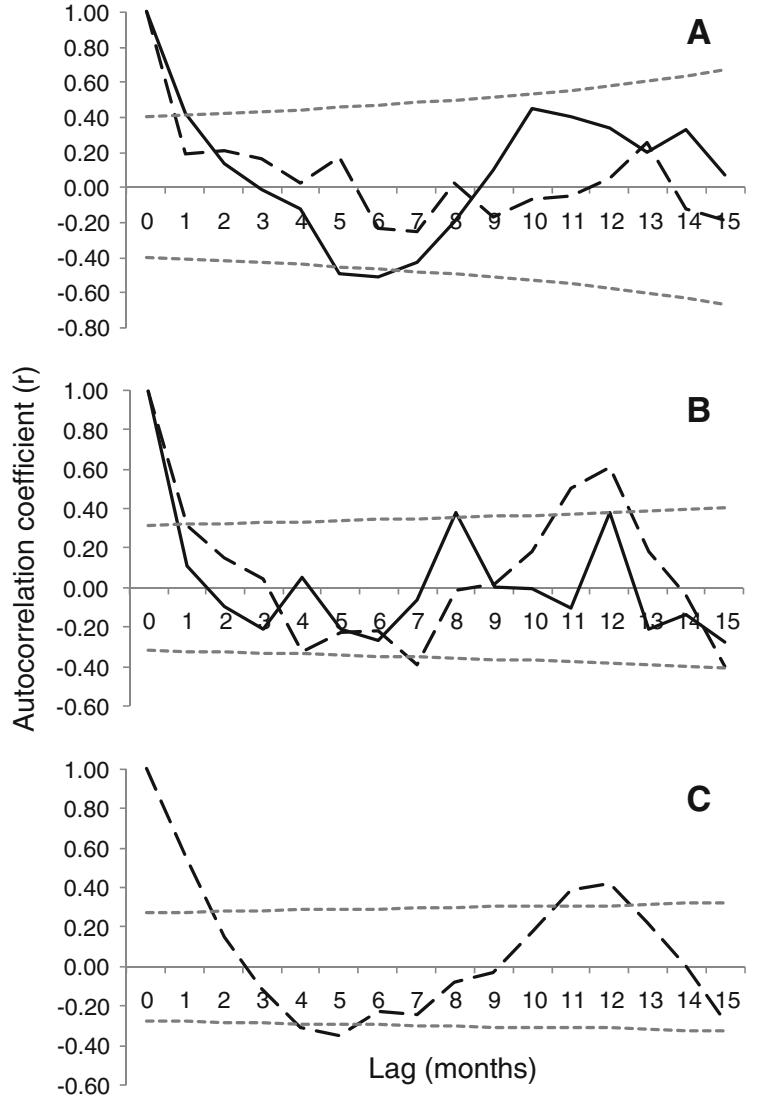

Fig. 3 Correlogram (lag up to 15 months) of catches per unit of effort (CPUE) of Stolothrissa tanganicae (plain line) and Lates stappersii (long dashes) from artisanal fishery at Kigoma (A) and Mpulungu (B) and industrial fishery at Mpulungu (C). Significance limits $(P<0.05)$ are indicated (small dashes) tanganicae. Furthermore the regression coefficient of this variable was the only significant one at the last step of the selection procedure. The tolerance parameter used to assess the redundancy between independent variables was low for the first three variables $(<0.4)$ indicating a high redundancy between them.

At Mpulungu, Stolothrissa tanganicae was not observed in the catches most of the time. The correlation between its CPUE from both artisanal and industrial fish statistics and $\mathrm{Chl} a$ measured at the field monitoring site was not significant as with other environmental variables (Tables 4 and 5). However, estimates of Chl $a$ from remote sensing, thanks to the capacity of this technique to monitor wide areas of the lake, showed clear surface patches of increased phytoplankton concentration (blooms) in the south of the lake, particularly along the Tanzanian coast (Fig. 5). These surface blooms took a few days to develop and spread towards the west in the pelagic area around the period of AprilMay each of the four studied years. Highest Chl $a$ values during those blooms reached $10 \mathrm{mg} \mathrm{m}^{-3}$ on $14 / 5 / 2005$ and $30 \mathrm{mg} \mathrm{m}^{-3}$ ranges on 4/5/2006. Although remote sensing and fish CPUE time series were not continuous, thus preventing a comparison day by day, the catches of Stolothrissa tanganicae in the south increased during the monitoring at the same time as these blooms. It is likely that part of the stock had migrated towards southern productive waters at this moment for short periods. The 
Fig. 4 Correlation coefficient of crosscorrelation between CPUE of Stolothrissa tanganicae (A) and Lates stappersii (B) (artisanal fishery) with Chl $a$ (surface), transparency (Secchi), mixing zone $\left(Z_{\mathrm{m}}\right)$, potential energy anomaly (PEA), and water temperature $(0-20 \mathrm{~m})$ at -15 to +15 month lag periods

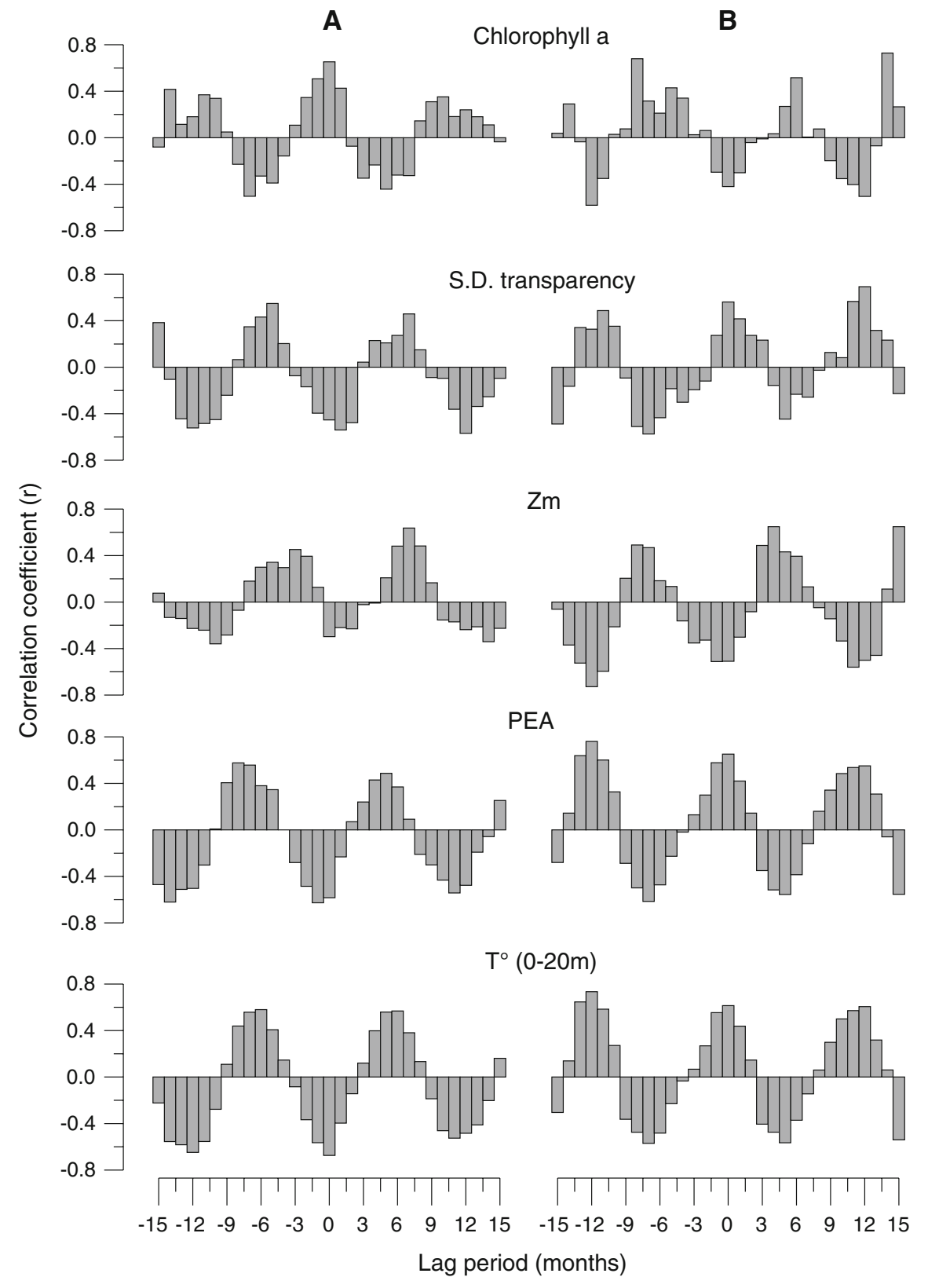

autocorrelation of $S$. tanganicae CPUE did not show significant peaks in the south, which indicated that the abundance pattern of this species was not similar here to that in the North (Fig. 4B).

The limnological variables and particularly the seasonal planktonic abundance explained better the fluctuation of abundance of Stolothrissa tanganicae than the absence/presence of Lates stappersii (Table 6).

Catches of Lates stappersii and limnological data

Transparency is positively correlated with the abundance of Lates stappersii ( $\mathrm{SL}>130 \mathrm{~mm}$ ) from 
Table 3 Synthesis of the multiple regression using a progressive stepwise procedure to select the explaining limnological variables and the possible predator-prey interactions in the
CPUE modelling in Kigoma and Mpulungu for artisanal fishing of Stolothrissa tanganicae (S.T.) and Lates stappersii (L.S.)

\begin{tabular}{|c|c|c|c|c|c|c|c|c|c|c|c|}
\hline \multirow{2}{*}{$\begin{array}{l}\text { Dependant } \\
\text { variable }\end{array}$} & \multicolumn{6}{|c|}{ Regression statistics } & \multicolumn{5}{|c|}{ Regression parameters } \\
\hline & $R^{2}$ & $\begin{array}{l}\text { Adjusted } \\
R^{2}\end{array}$ & $F$ & $\mathrm{df}^{\mathrm{a}}$ & $P$-value & $\mathrm{SEE}^{\mathrm{b}}$ & Parameter $^{\mathrm{c}}$ & $\begin{array}{l}\text { Stand. } \\
\text { regres. } \\
\text { coeff. }\end{array}$ & $\begin{array}{l}\text { Raw. } \\
\text { regres. } \\
\text { coeff. }\end{array}$ & $\begin{array}{l}\text { Partial } \\
\text { correlation }\end{array}$ & Tolerance \\
\hline \multirow{5}{*}{$\begin{array}{c}\text { CPUE } S . T \text {. } \\
\text { in Kigoma } \\
\text { artisanal } \mathrm{f} .\end{array}$} & 0.699 & 0.642 & 12.2 & 4.21 & $<0.00003$ & 64.96 & Intercept & & 3891.45 & & \\
\hline & & & & & & & $\mathrm{T}^{\circ} 0-20 \mathrm{~m}$ & -0.380 & 132.62 & -0.376 & 0.343 \\
\hline & & & & & & & Chl a RS & 0.764 & $302.25 *$ & 0.512 & 0.184 \\
\hline & & & & & & & K490 RS & -0.533 & -3395.44 & -0.408 & 0.212 \\
\hline & & & & & & & PEA & -0.250 & -6.11 & -0.293 & 0.455 \\
\hline \multirow{4}{*}{$\begin{array}{l}\text { CPUE } L . S . \text { in } \\
\text { Mpulungu } \\
\text { artisanal } \mathrm{f} .\end{array}$} & 0.633 & 0.559 & 8.6 & 3.15 & $<0.0015$ & 186.02 & Intercept & & 135.88 & & \\
\hline & & & & & & & PEA & 0.714 & $27.63 *$ & 0.721 & 0.78 \\
\hline & & & & & & & CPUE $S . T$. & -0.339 & -2.56 & -0.461 & 0.864 \\
\hline & & & & & & & Chl $a$ RS & -0.199 & -57.79 & -0.268 & 0.719 \\
\hline
\end{tabular}

$\overline{{ }^{a}}$ Degrees of freedom, ${ }^{\mathrm{b}}$ Standard error of estimate, ${ }^{\mathrm{c}}$ Parameters sorted in the forward stepwise selection order, * (bold) significant contribution of the variable $(t$-Student- $\mathrm{a}=0.05)$

Table 4 Pearson correlation coefficients between monthly artisanal fisheries CPUE of Stolothrissa tanganicae and Lates stappersii and limnological variables at Mpulungu from 07/2004 to 05/2006 (site CLIMP-M)

\begin{tabular}{|c|c|c|c|c|c|c|c|c|c|}
\hline & CPUE Stolo & CPUE Lstp & S.D. & $Z_{\mathrm{m}}$ & PEA & $\begin{array}{l}\text { Chla Fluo } \\
0-20 \mathrm{~m}\end{array}$ & $\begin{array}{l}\text { Chla } \\
\text { RS }\end{array}$ & K490 & $\mathrm{T}^{\circ} 0-20 \mathrm{~m}$ \\
\hline CPUE Stolo & 1.00 & & & & & & & & \\
\hline CPUE Lstp & -0.07 & 1.00 & & & & & & & \\
\hline S.D. & 0.26 & 0.56 & 1.00 & & & & & & \\
\hline$Z_{\mathrm{m}}$ & -0.13 & -0.51 & -0.51 & 1.00 & & & & & \\
\hline PEA & 0.14 & 0.65 & 0.74 & -0.86 & 1.00 & & & & \\
\hline Chla Fluo 0-20 m & -0.18 & -0.38 & -0.37 & 0.35 & -0.48 & 1.00 & & & \\
\hline Chla RS & -0.30 & -0.42 & -0.57 & 0.44 & -0.51 & 0.46 & 1.00 & & \\
\hline K490 RS & -0.42 & -0.41 & -0.63 & 0.45 & $-\mathbf{0 . 5 3}$ & 0.28 & 0.80 & 1.00 & \\
\hline $\mathrm{T}^{\circ} 0-20 \mathrm{~m}$ & 0.16 & 0.61 & 0.74 & -0.84 & 0.98 & -0.44 & -0.47 & $-\mathbf{0 . 5 5}$ & 1.00 \\
\hline
\end{tabular}

CPUE: catch per night of fishing by ring nets units, S.D. $=$ secchi disc transparency, $Z_{\mathrm{m}}=$ mixed layer depth, PEA $=$ potential energy anomaly from 0 to $100 \mathrm{~m}$, Chl $a$ fluo $0-20 \mathrm{~m}=$ average Chl $a$ measured by fluorometry at 0 and $20 \mathrm{~m}$, Chl $a$ RS = surface Chl $a$ measured by remote sensing, K490 RS = coefficient of extinction measured by remote sensing, $\mathrm{T}^{\circ} 0-20 \mathrm{~m}=$ average lake $\mathrm{T}^{\circ}$ at 0 and $20 \mathrm{~m}$; in bold: significant at $P<0.01$, in italic: significant at $P<0.05$

artisanal ( $r=0.56$ in 2004-2006) and industrial $(r=0.48$ in 2002-2006) fishery data (Figs. 6 and 7). When water transparency was below $7 \mathrm{~m}$ near Mpulungu, L. stappersii was not or very seldom caught.
This corresponds to an euphotic depth $Z_{\mathrm{eu}}$ of less than $20.5 \mathrm{~m}$. The correlation between the CPUE of $L$. stappersii and the transparency of water is lower but also significant at Kigoma $(r=0.31)$ (Table 2). 
Table 5 Pearson correlation coefficients between monthly industrial fisheries CPUE of clupeids (Stolothrissa tanganicae and Limnothrissa miodon), Lates stappersii and limnological variables at Mpulungu from 01/2002 to 05/2006

\begin{tabular}{|c|c|c|c|c|c|c|c|c|}
\hline CPUE Clup. & CPUE Lstp & S.D. & $Z_{\mathrm{m}}$ & PEA & $\begin{array}{l}\text { Chla fluo } \\
0-20 \mathrm{~m}\end{array}$ & Chla RS & K490 & $\mathrm{T}^{\circ} 0-20 \mathrm{~m}$ \\
\hline
\end{tabular}

\begin{tabular}{|c|c|c|c|c|c|c|c|c|c|}
\hline CPUE Clup. & 1.00 & & & & & & & & \\
\hline CPUE Lstp & -0.15 & 1.00 & & & & & & & \\
\hline S.D. & -0.24 & 0.48 & 1.00 & & & & & & \\
\hline$Z_{\mathrm{m}}$ & -0.14 & -0.70 & -0.34 & 1.00 & & & & & \\
\hline PEA & -0.17 & 0.66 & 0.59 & -0.67 & 1.00 & & & & \\
\hline Chla fluo $0-20 \mathrm{~m}$ & 0.17 & -0.33 & -0.40 & 0.12 & -0.39 & 1.00 & & & \\
\hline Chla RS & 0.10 & -0.38 & -0.74 & 0.22 & -0.45 & 0.57 & 1.00 & & \\
\hline K490 RS & 0.19 & -0.26 & -0.72 & 0.24 & -0.44 & 0.30 & 0.71 & 1.00 & \\
\hline $\mathrm{T}^{\circ} 0-20 \mathrm{~m}$ & -0.17 & 0.68 & 0.61 & -0.68 & 0.98 & -0.38 & -0.46 & -0.47 & 1.00 \\
\hline
\end{tabular}

Excepted for Chl $a$ RS and K490 RS: from 07/2002 to 09/2006 (site CLIMP-M); CPUE: catch per night of fishing by purse seine units, S.D. = secchi disc transparency, $Z_{\mathrm{m}}=$ mixed layer depth, Chl $a$ fluo $0-20 \mathrm{~m}=$ average Chl $a$ measured by fluorometry at 0 and $20 \mathrm{~m}, \mathrm{PEA}=$ potential energy anomaly from 0 to $100 \mathrm{~m}$, Chl $a \mathrm{RS}=$ surface $\mathrm{Chl} a$ measured by remote sensing, $\mathrm{K}_{490}$ $\mathrm{RS}=$ coefficient of extinction measured by remote sensing, $\mathrm{T}^{\circ} 0-20 \mathrm{~m}=$ average lake $\mathrm{T}^{\circ}$ at 0 and $20 \mathrm{~m}$; bold: significant at $P<0.01$, italic: significant at $P<0.05$

During the seasonal upwelling in Mpulungu (May to September), Lates stappersii is hardly ever caught. This can be observed with the significant negative correlation $(r=-0.70)$ between CPUE of industrial fishing and the mixing depth (Fig. 6). At this moment, lower DO and often lower transparency are observed. L. stappersii is probably moving toward more northern areas of the lake at this period.

The CPUE of Lates stappersii increases during the warm and wet season at Mpulungu. CPUE of this species shows strong positive correlation with both the water stability (PEA) and water temperature (Tables 5 and 6). This induces higher transparency as there is a decreased mixing of nutrients-rich deep water towards the surface.

Lates stappersii correlogram showed a seasonal cycle near Mpulungu with negative correlation at a lag of about 6 months and positive correlation with 1 year lag time (Fig. 3B, C). At Kigoma, no significant autocorrelations of $L$. stappersii CPUE were observed (Fig. 3A).

The cross-correlation with environmental variables indicated that cyclicity was strongly related to $\mathrm{T}^{\circ}$, PEA, $Z_{\mathrm{m}}$, transparency and Chl $a$ (Fig. 3B). For the same lag period, the correlation was of the opposite sign compared to $S$. tanganicae for all environmental variable excepted for $Z_{\mathrm{m}}$. The correlation was significant between CPUE of Lates stappersii and $Z_{\mathrm{m}}$ as a result of its very low abundance in the south during the deep mixing of the upwelling period from June to August. Limnological conditions appear thus also well linked to the presence of $L$. stappersii in its area of maximal abundance.

The results of the stepwise regression procedure used in the modelling of Lates stappersii CPUE for artisanal fishing in Mpulungu indicated partial correlations of $0.72,-0.46$ and -0.27 , respectively, for the PEA, the Chl $a$ and the CPUE of Stolothrissa tanganicae (Table 1). The multiple determination coefficient was 0.63. Only the regression coefficient of PEA was significant and confirmed its very strong positive effect on L. stappersii CPUE. The small and negative effects of the Chl $a$ and prey abundance were noted although those were not significant. In this case, the tolerance was higher than 0.4 for the three independent variables indicating a low redundancy between these variables. 


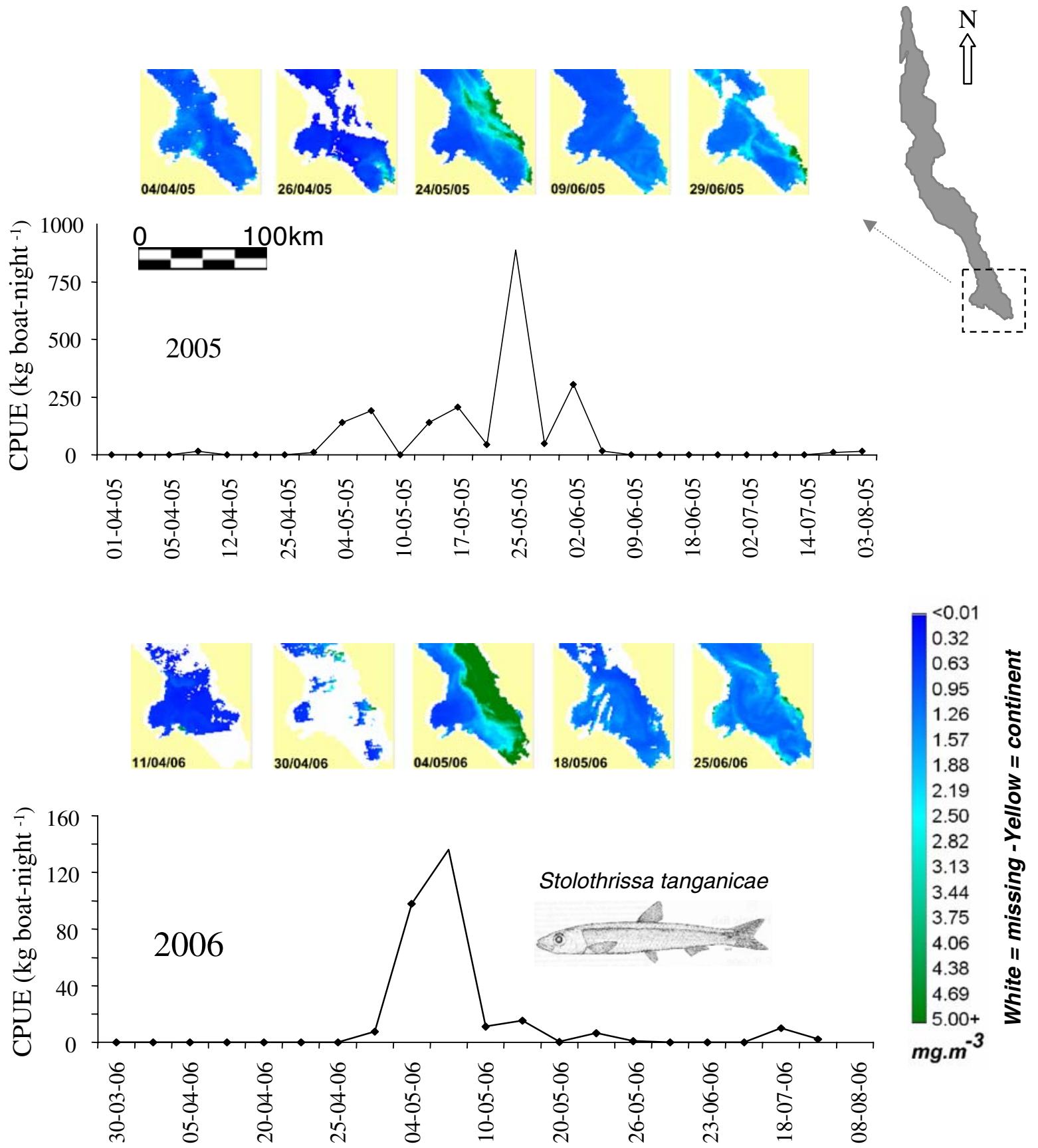

Fig. 5 Catches per unit of effort (artisanal ring nets) of Stolothrissa tanganicae in Mpulungu and algae blooms observed from MODIS remote sensing images of chl $a\left(\right.$ in $\mathrm{mg} \mathrm{m}^{-3}$ ) at the surface in the south of the lake at the time of trade wind inversion

The limnological conditions that are favourable for young Lates stappersii appear however similar to those for Stolothrissa tanganicae: low water stability and/or mixing epilimnion (Table 6). This probably explains that young L. stappersii are often caught together with S. tanganicae (Mannini et al., 1996). 


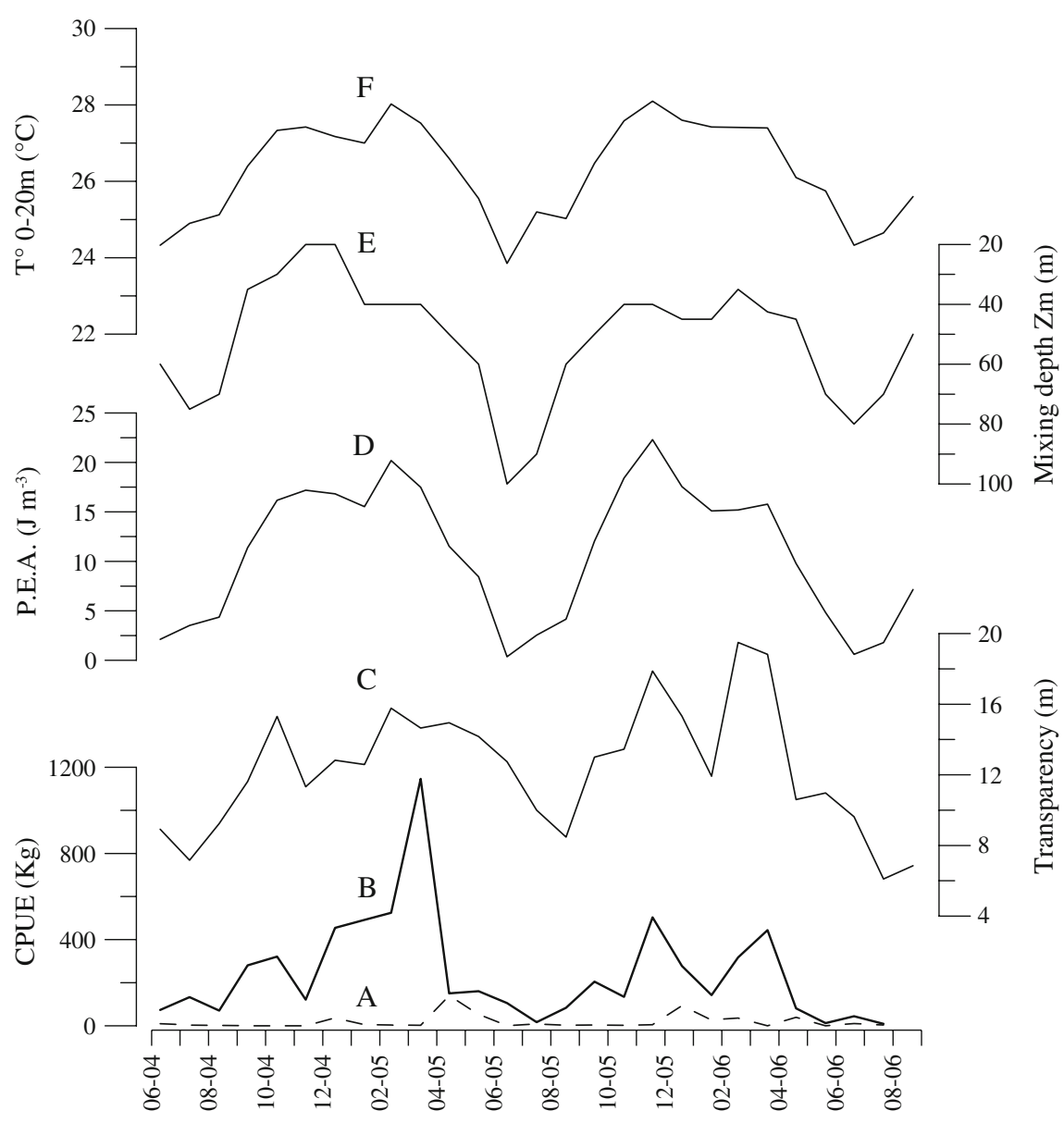

Fig. 6 Catch per unit of effort (ring nets) of Stolothrissa tanganicae (A), Lates stappersii (B), transparency (C), potential energy anomaly (D), mixing depth (E) and average water temperature (0-20 m) (F) at Mpulungu from June 2004 to August 2006

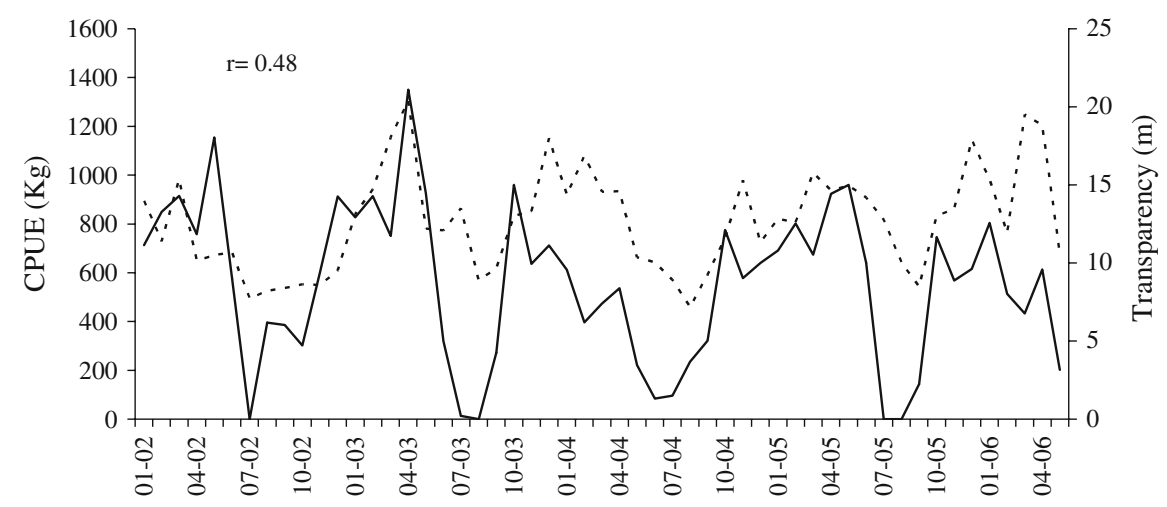

Fig. 7 Monthly CPUE of Lates stappersii (in bold) for industrial fishery and transparency (in dashes) at site CLIMP-M from January 2002 to May 2006 at Mpulungu 
Table 6 Epilimnion states characterised by limnological conditions linked with the presence/ abundance likelihood of Stolothrissa tanganicae and Lates stappersii in Lake Tanganyika waters (thermal stability, phytoplankton and zooplankton density, water transparency) in their main region of abundance

\begin{tabular}{lll}
\hline & \begin{tabular}{l} 
Epilimnion \\
\cline { 2 - 3 }
\end{tabular} & $\begin{array}{l}\text { "Mixing" } \\
\text { Dry season/wave up }\end{array}$ \\
\hline Thermal stability & Low & Wet season/wave down \\
Phytoplankton & High & High \\
Zooplankton & High & Low \\
Transparency & Low & High \\
Increased likelihood & Stolothrissa tanganicae & Lates stappersii \\
& Lates stappersii (juv.) & - \\
Decreased likelihood & Lates stappersii & Stolothrissa tanganicae \\
& - & Lates stappersii (juv.)
\end{tabular}

\section{Discussion}

The northern half of the lake in the Kigoma area was dominated by a clupeid-based fishery while the southern area near Mpulungu was a "perch" based fishery (Lates stappersii). This is in agreement with Mannini et al. (1999) who also noted that the catches of L. stappersii were mostly made up of juveniles in the north while adults appeared in the fishery further south.

Water mixing conditions and fish species abundance

The lake constantly alternated between high and low mixing states of the epilimnion on time scales linked to seasons (6 months) and internal waves periodicity (about 3 weeks). The mixing of deep waters towards the epilimnion increased during seasons of high wind as indicated by a reduced-gravity model, and light limitation could occur when mixing depth was greater than euphotic depth (Naithani et al., 2002, 2003, 2007a, b; Gourgue et al., 2007). The seasonal environmental cycles induce a clear autocorrelation of CPUE in the area of maximal density of the fish that is in the north for Stolothrissa tanganicae and in the south for Lates stappersii. Infra-seasonal variability in fish abundance may be explained by pulse production induced by internal waves (Plisnier \& Coenen, 2001) that may explain rapid changes of algae biomass (Hecky \& Fee, 1981) and euphotic depth (Langenberg et al., 2002).
Migrations of Stolothrissa and algae blooms

The CPUE of Stolothrissa tanganicae clearly increased when planktonic blooms were observed in the south (Fig. 5).

It is known that $S$. tanganicae is able to migrate (Chapman, 1976): displacements of $20 \mathrm{~km}$ per day have been reported (Coulter, 1991). However, fish shoals are not necessarily travelling a long distance. The data in this study originate from fishing areas $<80 \mathrm{~km}$ from Kigoma and Mpulungu, so fish appearing in the catches in the south may come from relatively nearby areas when compared to the size of the lake (650 km long). Fishermen know that "clupeids swim against the currents" (pers. com.), thus Stolothrissa could anticipate planktonic blooms and appear quickly in a favourable feeding area. The present results suggest that this is the case around April-May each year connected to change in trade winds. At this time, the main winds change from NE to SE and a surge results from change of thermocline tilting generating strong waves called "Yala" by fishermen in the south. Mixing of deep nutrient-rich water with the surface water takes place and some fish kills of Lates stappersii are observed in relation with low DO (Dept. of Fisheries \& pers. obs.). Remote sensing has allowed observation of those planktonic blooms in each of 4 years of this study. Similar waves are also known around September every year at the time of the second trade wind direction change from SE to NE (Plisnier \& Coenen, 2001). However these could not be detected by remote sensing because of cloudiness. Stolothrissa 
tanganicae is mainly a zooplanktonophage species (Coulter, 1991). The increase of $S$. tanganicae abundance in phytoplankton-rich waters in the south is probably resulting from increasing zooplankton abundance in these waters. Phytoplankton and zooplankton were previously shown to be well correlated at Lake Tanganyika (Rufli \& Chapman, 1976; Kurki et al., 1999).

Water transparency and fish catches

The monthly CPUE of Lates stappersii $>130 \mathrm{~mm}$ SL is significantly correlated with the transparency of water. The abundance of adult $L$. stappersii species in one area of the lake could be explained by favourable transparency allowing them to catch their prey more efficiently. However, it could also be that the light used by fishermen could be seen from a longer distance when water is more transparent, thus attracting more fish. In this case, a high inverse correlation between CPUE and moonlight could also be expected as the fishermen's light should have a maximal effect in dark conditions, but preliminary investigation did not show this. Coulter (1991) and Phiri \& Shirakihara (1999) noted generally higher abundance of Lates stappersii in deep and steep basins. As those areas often display higher transparency, this supports the hypothesis of the importance of transparency for the high abundance of L. stappersii rather than a technical artefact.

Vision is a primary modality in the behaviour of schooling fish (Davis \& Olla, 1992) and it is probably also important for clupeid fishes. Coulter (1991) noted the probable importance of the visual sense in clupeids as indicated by the large size of their optic lobes. Our results show that the threshold of transparency for Stolothrissa tanganicae is certainly much lower than for Lates stappersii.

\section{North-South difference}

Some limnological differences are known between the north and the south of the lake. The epilimnion is thinner in the north (Plisnier et al., 1996; Descy et al., 2005), which is linked with important differences in the oxic layer depth. Anoxic conditions were found at about $120 \mathrm{~m}$ depth in the north of the lake as against $180 \mathrm{~m}$ depth in the south (De Wever et al., 2005). Previous observations suggest that Lates stappersii adults have a stronger DO requirement than clupeids. Fish kills of Lates stappersii have been observed previously at times of low DO (pers. obs.) while no fish kills of clupeids were reported. Pearce (1988) indicated that adult $L$. stappersii seem to prefer upper water layers. Large predatory species generally require higher levels of oxygen (Magnuson et al., 1985).

Differences in plankton composition and abundance have been found between the north and the south of the lake (Kurki et al., 1999). Phytoplankton $(>5 \mu \mathrm{m})$ species were more abundant in the north while some planktonic groups (eukaryotic phytoplankton $(<5 \mu \mathrm{m})$, picocyanobacteria, bacteria...) were less abundant there than in the south. More medusae and cyclopoida have also been reported in the north while more calanoids and shrimps are found in the south. The diet of $L$. stappersii varies between the northern and southern ends of the lake. Stolothrissa tanganicae is a principal food item at Kigoma but, in the south, pelagic shrimps form the main diet or Lates stappersii (Mannini et al., 1999) indicating that this species is certainly not exclusively a fish predator.

The physical thermal structure of Lake Tanganyika, linked to climate, drives the chemical and biological environment. A north-south environmental gradient on this $650 \mathrm{~km}$ long lake could explain the different distribution of pelagic fishes in the present period. The deeper oxygenated waters in the south and the presence of an abundant population of shrimp to forage could explain the more abundant population of $L$. stappersii there while $S$. tanganicae could find optimum feeding conditions, while better escaping predation, in the north.

Predator-prey relationship is not satisfactory as a main explanation of changes in abundance

Predator-prey relationship has often been quoted to explain the apparently inverted species abundance between Lates stappersii and Stolothrissa tanganicae from the catches data (Henderson et al., 1972; Pearce, 1988; Roest, 1988) in Lake Tanganyika. However, this hypothesis alone does not satisfactorily explain shortterm changes in fish abundance. It was proposed during periods when limnological observations were very seldom carried out at the same time and confronted directly to fish catches data. Adult 
populations of $L$. stappersii and S. tanganicae maintain separate centres of population density probably in relation with the $\mathrm{N}-\mathrm{S}$ limnological differences. The populations of the two species do however overlap and, from time to time, high densities of one species may be found in the "territory" of the other though generally the two species intermingle only at the margins of their populations (Pearce, 1988). We suggest that this overlap may happen at "intermediate level" of planktonic abundance and water transparency (in the range from 7 to $12 \mathrm{~m}$ ). Below this transparency level, $L$. stappersii CPUE is very low as this appears unfavourable for visual predation while, at higher level, the planktonic biomass in surface water is low, which would be unfavourable for the presence of $S$. tanganicae. During FAO trawling surveys, no high concentration of $L$. stappersii preying upon S. tanganicae schools has ever been observed (Mannini, 1998). Stolothrissa tanganicae abundance has been drastically reduced over the recent decades in the south (Coenen et al., 1998), but this has not affected L. stappersii, which feeds mainly on shrimps there (Mannini et al., 1999). There is thus not a simple predator-prey relationship between $L$. stappersii and S. tanganicae.

Limnological variability (particularly planktonic concentration) is more correlated to the variable abundance of Stolothrissa tanganicae than the presence/absence of Lates stappersii while transparency, and possibly DO concentration, could drive L. stappersii distribution. As the limnological environment fluctuates constantly due to meteorological and hydrodynamical changes, so does the abundance of S. tanganicae and L. stappersii. Patchiness in fish distribution could result from patchiness in the lake environment, such as driven by seasonality and internal waves (De Bont, 1972; Plisnier \& Coenen, 2001).

Remote sensing applications for fisheries research

Remote sensing appears here for the first time as a potentially interesting technique for fisheries applications at Lake Tanganyika as significant correlation was observed between surface Chl $a$ and Stolothrissa tanganicae. A good demonstration of its usefulness is the increased CPUE of $S$. tanganicae in the south, which coincided with phytoplankton blooms observed by remote sensing. These could not have been detected during the limnological monitoring at one site. Complete daily time series could not be obtained however because of cloudiness, particularly during the rainy period. Some procedures are under investigation for partially filling spatial and temporal gaps in time series. Interesting developments could make use of new available captors, different interpolation algorithms like the DINEOF method and spatio-temporal clustering procedures taking into consideration spatial and temporal connexity in addition to the proximity in the remote sensing parameter space (Chl $a, \mathrm{~K} 490 \ldots)$.

\section{Conclusions}

The different habitat distribution of the species in the lake and the recently increased knowledge of the food of Lates stappersii have indicated that the previously considered avoidance of Stolothrissa tanganicae prey towards L. stappersii in a simple predator-prey interaction does not satisfactorily explain their short-term fluctuations. The use of fisheries data alone does not consider the limnological conditions and their influence on the abundance of $S$. tanganicae and L. stappersii.

The use of remote sensing images has been useful for the observation of planktonic blooms taking place at the same time as increases in abundance of Stolothrissa tanganicae. This technique constitutes an interesting potential application for fisheries at Lake Tanganyika.

The present results suggest that short-term fluctuations of Stolothrissa tanganicae and Lates stappersii are mainly correlated with limnological variability at Lake Tanganyika. It is clear that in the future, fisheries studies need to record simultaneous limnological observations from fixed field stations together with extensive monitoring using remote sensing as well as from multidisciplinary lake wide cruises.

Planktonic abundance is an important driver for Stolothrissa tanganicae abundance at a particular time and location in the lake while transparency and, probably, dissolved oxygen seem favourable conditions for adult Lates stappersii. An increased understanding of spatial and temporal limnological variability is necessary to understand the distribution of pelagic fish species in Lake Tanganyika and fisheries changes. 
Acknowledgements This study was funded by the Federal Science Policy, Belgium (BELSPO) in the framework of A STEREO/CLIMFISH project ("Climate change impact on the sustainable use of Lake Tanganyika fisheries"). Many thanks to C. Petit, J. Vandenabeele, K. Ruddick, H. Gonz and J.-C. Micha for their suggestions during this project. The Belgian Development Cooperation financed the monitoring at Lake Tanganyika through a framework agreement with the Royal Museum for Central Africa (in Tervuren). We greatly appreciated the support of G. Gryseels, and the help of M. De Scheemaecker. H. Hughes has contributed useful comments. We thank P. Bwathondi, B. Ngatunga, D. Chitamwebwa and staff at TAFIRI (Tanzanian Fisheries Research Institute). At the Department of Fisheries in Zambia (DOF), we particularly thank C. Kapasa, H. Phiri, D. Synienza and staff at Mpulungu for their involvement. A. Cohen, K. Lezzar, E. Michel, C. O'Reilly of the Nyanza project (University of Arizona) have provided appreciated collaboration. At Namur University, B. Leporcq, F. Darchambeau, S. Sténuite, V. Gosselain, Y. Mine and others have helped the project. Judy and John Wickens have provided an appreciated help. We thank J.-M. Beckers from the GHERAGO (ULg) and his collaborators. We thank A. Azcarate and A. Barth from the Ocean Circulation Group (College of Marine Science, University of South Florida). Thanks to S. Loiselle (Università degli Studi di Siena) for useful comments. E. Deleersnijder is a Research Associate with the Belgian National Fund for Scientific Research (FNRS).

\section{References}

Bannerot, S. P. \& C. B. Austin, 1983. Using frequency distributions of catch per unit effort to measure fish-stock abundance. Transactions of the American Fisheries Society 112: 608-617.

Barnes, J. T., A. D. Maccall, L. D. Jacobson \& P. Wolf, 1992. Recent population trends and abundance estimates for the pacific sardine (Sardinops sagax). California Cooperative Oceanic Fisheries Investigations Reports 33: 60-75.

Bergamino, N., S. A. Loiselle, A. Cozar, A. M. Dattilo, L. Bracchini \& C. Rossi, 2007. Examining the dynamics of phytoplankton biomass in Lake Tanganyika using Empirical Orthogonal Functions. Ecological modelling 204: 156-162.

Chèné, G., 1975. Etude des problèmes relatifs aux fluctuations piscicoles du lac Tanganyika. Unpublished Mémoire de licence, University of Liège, Belgium: $108 \mathrm{pp}$.

Chapman, D. W., 1976. Summary of biological research on lake Tanganyika from July 1973 to September 1976. United Nations Food and Agriculture Organisation Report FI:DP URT/71/012 46: 22 pp.

Cocquyt, C. \& W. Vyverman, 2005. Phytoplankton in Lake Tanganyika: a comparison of community composition and biomass off Kigoma with Previous Studies 27 Years Ago. Journal of Great Lakes Research 31: 535-546.

Coenen, E. J., P. Paffen \& E. Nikomeze, 1998. Catch per unit of effort (CPUE) study for different areas and fishing gears of Lake Tanganyika. FAO/FINNIDA Research for the Management of Fisheries on Lake Tanganyika. GCP/ RAF/271/FIN-TD/80 (En): 86 pp.
Coulter, G. W., 1977. Approaches to estimating fish biomass and potential yield in Lake Tanganyika. Journal of Fish Biology 11: 393-408.

Coulter, G. W. (ed.), 1991. Lake Tanganyika and its life. Oxford University Press, New York: 354 pp.

Dagnelie, P., 1986. Analyse statistique à plusieurs variables. Les Presses Agronomiques de Gembloux: 362 pp.

Davis, M. W. \& B. L. Olla, 1992. The role of visual cues in the facilitation of growth in a schooling fish. Environmental Biology of Fish 34: 421-424.

De Bont, A. F., 1972. La productivité du Lac Tanganyika. Verhandlungen der Internationalen Vereinigung für theoretische und angewandte. Limnologie 18: 656-660.

De Wever, A., K. Muylaert, K. Van Der Gucht, S. Pirlot, C. Cocquyt, J.-P. Descy, P.-D. Plisnier \& W. Vyverman, 2005. Bacterial community composition in Lake Tanganyika: vertical and horizontal heterogeneity. Applied and Environmental Microbiology 71: 5029-5037.

De Wever, A., K. Muylaert, C. Cocquyt, J. Van Wichelen, P.D. Plisnier \& W. Vyverman, 2007. Seasonal and spatial variability in the abundance of auto- and heterotrophic plankton in Lake Tanganyika. Fundamental and Applied Limnology 170: 49-63.

Descy, J.-P., M.-A. Hardy, S. Stenuite, S. Pirlot, B. Leporcq, I. Kimirei, B. Sekadende, S. R. Mwaitega \& D. Sinyenza, 2005. Phytoplankton pigments and community composition in Lake Tanganyika. Freshwater Biology 50: 668-684.

Ellis, C. M. A., 1978. Biology of Luciolates stappersi in Lake Tanganyika (Burundi). Transactions of the American Fisheries Society 107: 557-566.

FAO, 1984. Papers presented at the Expert Consultation on the regulation of fishing effort (fishing mortality). Rome, 1726 January 1983. A preparatory meeting for the FAO World Conference on fisheries management and development. United Nations Food and Agriculture Organisation. Fisheries Report 289: 214 pp.

Fennel, K. \& E. Boss, 2003. Subsurface maxima of phytoplankton and chlorophyll: steady-state solutions from a simple model. Limnology and Oceanography 48(4): 1521-1534.

Gourgue, G., E. Deleersnijder \& L. White, 2007. Toward a generic method for studying water renewal, with application to the epilimnion of Lake Tanganyika. Estuarine, Coastal and Shelf Science 74: 628-640.

Gulland, J. A., 1983. Fish stock assessment. A manual of basic methods. John Wiley \& Sons, Chichester: 223 pp.

Hecky, R. E. \& E. J. Fee, 1981. Primary production and rates of algal growth in Lake Tanganyika. Limnology and Oceanography 26: 532-547.

Henderson, H. F., G. W. Coulter, M. J. Mann \& G. Wetherall, 1972. Predator-prey relationships and the pelagic fishery potential in Lake Tanganyika with particular reference to the purse seine fishery of Burundi. United Nations Food and Agriculture Organisation BD1/70/508: 1-43.

Herman, C., 1978. La pêche dans le lac Tanganyika: situation actuelle et perspectives de développement. United Nations Food and Agriculture Organisation. Committee for Inland Fisheries of Africa CPCA 5: 16-41.

Jackson, R. B., S. R. Carpenter, C. N. Dahm, D. M. McKnight, R. J . Naiman, S. L. Postel \& S. W. Running, 2001. Water in a changing world. Ecological Application 11(4): 1027-1045. 
Kimirei, I. A. \& Y. D. Mgaya, 2007. Influence of environmental factors on seasonal changes in clupeid catches in the Kigoma area of Lake Tanganyika. African Journal of Aquatic Science 32: 291-298.

Kurki, H., P. Mannini, I. Vuorinen, E. Aro, H. Mölsä \& O. V. Lindqvist, 1999. Macrozooplankton communities in Lake Tanganyika indicate food chain differences between the northern part and the main basins. Hydrobiologia 407: 123-129.

Langenberg, V., L. W. Mwape, K. Tschibangu, J.-M. Tumba, A.-A. Koelmans, R. Roijackers, K. Salonen, J. Sarvala \& H. Mölsä, 2002. Comparison of thermal stratification, light attenuation and Chlorophyll $a$ dynamics between the ends of Lake Tanganyika. Aquatic Ecosystem Health \& Management 5: 255-265.

Magnuson, J. J., A. L. Beckel, E. Mills \& S. B. Brandt,1985. Surviving winter hypoxia: behavioral adaptations of fishes in a northern Wisconsin winterkill lake. Environmental Biology of Fishes 14: 241-250.

Mangel, M. \& P. E. Smith, 1990. Presence-absence sampling for fisheries management. Canadian Journal of Fisheries and Aquatic Sciences 47: 1875-1887.

Mann, M. J., F. Bashirwa, C. M. Ellis, J. B. Nahabakomeye \& H. O. Enderlein. 1973. A preliminary report on fish biology and stock assessment in Lake Tanganyika (Burundi). United Nations Food and Agriculture Organisation Report Fl:DP/BD1/73/020/5: 1-58.

Mannini, P., 1998. Geographical distribution patterns of pelagic fish and macrozooplankton in Lake Tanganyika. FAO/ FINNIDA Research for the Management of Fisheries on Lake Tanganyika. GCP/RAF/271/FIN-TD/83 (En): 125 pp.

Mannini, P., E. Aro, I. Katonda, B. Kassaka, C. Mambona, G. Milindi, P. Paffen \& P. Verburg, 1996. Pelagic fish stocks of Lake Tanganyika: biology exploitation. FAO/ FINNIDA Research for the Management of Fisheries on Lake Tanganyika.GCP/RAF/271/FIN-TD/53 (En): 85 pp.

Mannini, P., I. Katonda, B. Kissaka \& P. Verburg, 1999. Feeding ecology of Lates stappersii in Lake Tanganyika. Hydrobiologia 407: 131-139.

Mölsä, H., J. E. Reynolds, E. J. Coenen \& O. V. Lindqvist, 1999. Fisheries research towards resource management on Lake Tanganyika. Hydrobiologia 407: 1-24.

Naithani, J. \& E. Deleersnijder, 2004. Are there internal Kelvin waves in Lake Tanganyika? Geophysical Research Letters 31, doi:10.1029/2003GL019156.3.

Naithani, J., E. Deleersnijder \& P.-D. Plisnier, 2002. Origin of intraseasonal variability in Lake Tanganyika. Geophysical Research Letters 29, doi:10.1029/2002GL015843.

Naithani, J., E. Deleersnijder \& P.-D. Plisnier, 2003. Analysis of wind-induced thermocline oscillations of Lake Tanganyika. Environmental Fluid Mechanics 3: 23-39.

Naithani, J., F. Darchambeau, E. Deleersnijder, J.-P. Descy \& E. Wolanski, 2007a. Study of the nutrient and plankton dynamics in Lake Tanganyika using a reduced-gravity model. Ecological Modelling 200: 225-233.

Naithani, J., P.-D. Plisnier \& E. Deleersnijder, 2007b. A simple model of the eco-hydrodynamics of the epilimnion of Lake Tanganyika. Freshwater Biology 52: 2087-2100.

O'Reilly, C. M., S. R. Alin, P.-D. Plisnier, A. S. Cohen \& B. A. McKee, 2003. Climate change decreases aquatic ecosystem productivity of Lake Tanganyika, Africa. Nature 424: 766-768.

Patti, B., C. Guisande, A. R. Vergara, I. Riveiro, I. Maneiro, A. Barreiro, A. Bonanno, G. Buscaino, A. Cuttitta, G. Basilone \& S. Mazzola, 2008. Factors responsible for the differences in satellite-based chlorophyll a concentration between the major global upwelling areas. Estuarine, Coastal and Shelf Science 76: 775-786.

Pearce, M. J., 1988. Some effects of Lates species on pelagic and demersal fish in Zambian waters of Lake Tanganyika. In Lewis, D. (ed.), Predator-prey relationships, population dynamics and fisheries productivities of large African lakes. United Nations Food and Agriculture Organisation. Committee for Inland Fisheries of Africa 15: 69-87.

Phiri, H. \& K. Shirakihara, 1999. Distribution and seasonal movement of pelagic fish in southern Lake Tanganyika. Fisheries Research 41: 63-71.

Plisnier, P.-D., 2000. Recent climate and limnology changes in Lake Tanganyika. Verhandlung internationale Vereinigung für theoretische und angewandte. Limnologie 27: 2670-2673.

Plisnier, P.-D. \& E. C. Coenen, 2001. Pulsed and dampened annual limnological fluctuations in Lake Tanganyika. In Munawar, M. \& R. Hecky (eds), The Great Lakes of the World (GLOW): food-web, health and integrity. Ecovision World Monograph Series, Leiden: 81-94.

Plisnier, P.-D. \& J.-P. Descy (eds), 2005. Climlake: climate variability as recorded in Lake Tanganyika. Final Report (2001-2005). Belgian Sciences Policy Office - Global change, ecosystems and biodiversity: $105 \mathrm{pp}$.

Plisnier, P.-D., J.-C Micha \& V. Frank, 1988. Pêche et biologie des principales espèces de poissons du lac Ihema (Rwanda). Presses Universitaires de Namur: 212 pp.

Plisnier, P.-D., V. Langenberg, L. Mwape, D. Chitamwebwa, K. Tshibangu, \& E. J. Coenen, 1996. Limnological sampling during an annual cycle at three stations on Lake Tanganyika (1993-1994). FAO/FINNIDA Research for the Management of the Fisheries on Lake Tanganyika. GCP/RAF/271/FIN-TD/46 (En): 124 pp.

Plisnier, P.-D., D. Chitamwebwa, L. Mwape, K. Tshibangu, V. Langenberg \& E. Coenen, 1999. Limnological annual cycle inferred from physical-chemical fluctuations at three stations of Lake Tanganyika. Hydrobiologia 407: $45-58$.

Plumptre, A. J., T. R. B. Davenport, M. Behangana, R. Kityo, G. Eilu, P. Ssegawa, C. Ewango, D. Meirte, C. Kahindo, M. Herremans, J. K. Peterhans, J. D. Pilgrim, M. Wilson, M. Languy \& D. Moyer, 2007. The biodiversity of the Albertine Rift. Biological Conservation 134: 178-194.

Poll, M., 1953. Poissons non Cichlidae. Résultats scientifiques de l'exploration hydrobiologique du lac Tanganika (19461947). Institut Royal des Sciences Naturelles de Belgique 3: $1-251$.

Roest, F. C. 1988. Predator-prey relations in northern Lake Tanganyika and fluctuations in the pelagic fish stocks. In Lewis, D. (ed.), Predator-prey relationships, population dynamics and fisheries productivities of large African lakes. Committee For Inland Fisheries of Africa Occas. Pap. 15: 104-129.

Roest, F. C., 1993. Dynamics of the fish stocks of northern Lake Tanganyika in 1973-1980 with special reference to 
Limnothrissa miodon. In Marshall, B. E. \& R. Mubamba (eds), Symposium on biology, stock assessment and exploitation of small pelagic fish species in the African Great Lakes region. Bujumbura, 25-28 November 1992. United Nations Food and Agriculture Organisation. Committee for Inland Fisheries of Africa 19: 168-175.

Rohlf, F. J. \& R. R. Sokal, 1995. Statistical tables, 3rd ed. W. H. Freeman \& Co, New York: 199 pp.

Rufli, H. \& D. W. Chapman, 1976. Preliminary analysis of zooplankton sampling and estimates of fish abundance in Lake Tanganyika in October 1975. Lake Tanganyika fishery research and development project. United Nations Food and Agriculture Organisation FI:DP/URT/71/012/ 31: $14 \mathrm{pp}$.

Sanyanga, R. A., C. Machena \& N. Kautsky, 1995. Abundance and distribution of inshore fish in fished and protected areas in Lake Kariba, Zimbabwe. Hydrobiologia 306: $67-78$.
Simpson, J. H., P. B. Tett, M. L. Argoteespinoza, A. Edwards, K. J. Jones \& G. Savidge, 1982. Mixing and phytoplankton growth around an island in a stratified sea. Continental Shelf Research 1: 15-31.

Uthermöhl, H., 1931. Neue Wege in der quantitativen Erfassung des Planktonts. Verhandlungen der internationalen Vereinigung für theoretische und angewandte. Limnologie 5: 567-596.

Verburg, P., R. E. Hecky \& H. Kling, 2003. Ecological consequences of a century of warming in Lake Tanganyika. Science 301: 505-507.

Worm, B., E. B. Barbier, N. Beaumont, J. E. Duffy, C. Folke, B. S. Halpern, J. B. C. Jackson, H. K. Lotze, F. Micheli, S. R. Palumbi, E. Sala, K. A. Selkoe, J. J. Stachowicz \& R. Watson, 2006. Impacts of biodiversity loss on ocean ecosystem services. Science 314(5800): 787-790. 